\title{
DECLINE OF ARABLE FLORA DIVERSITY IN ISTRIA (FROM THE YEAR 2005 TO THE YEAR 2017) ${ }^{4}$
}

\begin{abstract}
Changes in floristic composition of weed flora were assessed comparing two phytocoenological surveys carried out during vegetation seasons in 2005 and in 2017 on the Istrian Peninsula. A total of 50 fields (row crops, cereals, alfalfa fields, orchards/vineyards and ruderal areas) were surveyed for each of the sampling time using Braun-Blanquet cover-abundance scale. Altogether 175 vascular plant species were recognized in both investigations. The most abundant species in 2005 were Avena fatua, Setaria verticilata, Lolium multiflorum and Veronica persica. In the recent survey these species became very rare or were even not detected in some habitats. In contrast, some species with very low relative abundance or not recorded in the earlier survey were found abundant in 2017. These are: Pastinaca sativa, Conyza canadensis, Picris echioides, Polygonum aviculare, and Heliotropium europaeum. The species richness was significantly higher in the earlier survey when $143(82 \%)$ weeds were detected compared to only 97 species (55\%) found in 2017. Only 64 species were found in both surveys, and these were considered frequent weeds. The comparison of weed communities from the earlier to the recent survey reflects the reduction of the weed flora at the regional scale, as well as at the field scale. The mean values of Shannon-Wiener diversity index were also higher in the earlier period and it decreased over time, particularly in row crops, cereals and ruderal habitats. This decrease was related to decline of species richness, and to the increase in inequality in the relative abundance of species. On the whole, canonical correspondence analysis indicated the major variations in species composition between different habitats.
\end{abstract}

Key words: biodiversity, arable weeds, field surveys, Istria, Croatia

\section{INTRODUCTION}

Intensive agriculture tends to have negative impacts on weed biodiversity. Arable weeds have been classified among the most threatened groups of vascular plants in Europe and many agrestals have become extinct locally and/or regionally (Storkey et al., 2012). Significant changes in weed

1 PhD, Professor, Faculty of Agriculture, University of Osijek, V. Preloga 1, 54000 Osijek, Croatia.

E-mail:estefanic@pfos.hr

2 PhD, Senior Lecturer, Polytechnic of Rijeka, K. Huguesa, 52440 Poreč, Croatia. E-mail:vesna.kovacevic@veleri.hr

3 PhD, College Professor, Polytechnic of Slavonski Brod, Dr. M. Budaka 1, 35000 Slavonski Brod, Croatia.

E-mail: slavica.antunovic@vusb.hr

4 Received: 15 January 2018; Accepted: 15 March 2018 
communites have been detected in many countries (Hilbig, Bachthaler, 1992, Storkey et al., 2010, Kolarova et al., 2013). Many studies reported reduction in species diversity and the emergence of weed species with wide ecological amplitudes and difficulty to control (Lososová, Simonová, 2008). Albrecht (1995), for example, described changes in different German regions where average declines in species richness during the last five decades ranged between $10 \%$ and $70 \%$. Also, a meta-analysis of changes in the number of weed species across Europe showed on average 20\% reduction of species per field between 1939 and 2012 (Richner et al., 2014).

Many of weed species have become rare and are red-listed in various European countries. The situation in Switzerland is particularly dramatic, since 137 out of 176 arable flora are red-listed. Moreover, a study in UK (Oxfordshire) showed that weed species that had already been rare 40 years earlier were mostly absent from arable fields at the time the study was conducted (Sutclife, Kay, 2000).

The main reasons for the decline in arable flora lays in rapid changes in agricultural practice since the 1950s when the selection pressure on weed communities was significantly increased. The increase in inputs of industrial fertilisers, pesticides and other chemicals, effective seed cleaning and shifting the timing of sowing from spring to autumn for many crops dramatically altered the arable flora of Europe (Andreasen, Streibig, 2010). Also, the transition from conventional cropping systems to alternative ones (e.g. organic farming, and integrated pest management) affected weed communities at the field and landscape scale (Gaba et al., 2017). Moreover, this temporal changes in weed flora shifts are not visible only in the aboveground vegetation, but also in size and composition of weed seedbank (Barberi et al., 1998, Barberi \& Lo Cascio, 2001).

The effects of agricultural intensification at field and landscape levels on the species richness of weed communities in the Republic of Croatia is still not well documented. The lists of threatened weeds for the continental part of Croatia were given by Hulina $(1998,2005)$.

Therefore, the objective of this study has been to explore if there is a visible temporal change in weed species number and composition in main agricultural habitats of the agricultural region of the Istrian Peninsula with a particular attention on orchards/vineyards, row crops, cereals, alfalfa, and surrounding ruderal habitats.

\section{MATERIAL AND METHODS}

\section{1 Study area}

A phytocoenological survey was initiated in 2005 and repeated in 2017 in Istria, the largest peninsula located in the northernmost part of the Adriatic sea. The peninsula covers the surface of 3.476 square kilometers, and the largest part ( 3.130 square kilometers) belongs to the Republic of Croatia. Agriculture has a long tradition in this region, although only $39,72 \%$ of the territory is under cultivation. In the last couple of years, a great attention has been paid to the revitalisation of agriculture, since the majority of arable land (84,86\%) belongs to small family farms and it represents a combination of agricultural land and natural vegetation. The rest of the area belongs 
to non-irrigated fields (8,28\%), permanetnt crops, mainly vineyards, orchards and olive growes $(5,78 \%)$ and pastures $(1,08 \%)$.

The investigated area covers the so called "gray" - fertile inner land mainly with a flish soil (sedimentary rock with grey clay rich in limestone) and "red" - coastline part of the peninsula named for its terracotta coloured soil (terra rossa or red clay soil) rich in iron (Racz, 2003). The continental plains and valleys, are primarily utilized for crop production, while closer to the sea, red lands are used for cultivation of vineyards and orchards (mainly olives).

Coastal area experiences very pleasant Mediterranean climate with the highest average temeperatures averaging $24{ }^{\circ} \mathrm{C}$ in August, and lowest averaging $5{ }^{\circ} \mathrm{C}$ in January. Average yearly amount of precipitation in this area is from $800 \mathrm{~mm}$ to $1200 \mathrm{~mm}$. Mediterranean climate gradually changes towards the continent and it passes into continental, due to cold air circulating from the mountains and the vicinity of the Alps.

\subsection{Vegetation sampling}

This paper analyses a datasets of weed flora collected on arable lands and ruderal areas across the Istria peninsula in 2005 and in 2017. A total of 50 fields were surveyed for each of the sampling time. The inventored sites were classified into following agricultural categories: a) orchards/vineyards, b) alfalfa fields, c) row crops, d) cereals and e) ruderal habitats. Relevés in each five agricultural categories were uniformly arranged. The fields from the recent surveys (2017) were chosen as close as possible to the fields surveyed in 2005.

Fully developed vegetation was monitored as follows: cereals and alfalfa in June and July, and wide row-crops, orchards, vineyards and ruderal areas in August and September. At each location, one phytocoenological relevé of a standard size $100 \mathrm{~m}^{2}$ was recorded. The weed surveys were restricted to field edges in order to maximize the detection of characteristic arable weeds (Marshall, Moonen, 2002). The species coverage was estimated using seven-degree Braun-Blanquet cover-abundance scale (Braun-Blanquet, 1964). Braun-Blanquet indices of species cover $(r,+, 1,2,3,4$ and 5$)$ were transformed to percentage cover with the following intervals: 0-1, 1-5, 5-10, 10-25, 25-50, 50-75 and $75-100 \%$ ). The mean of each interval was used as the absolute species cover (Van Der Maarel, 1979).

\subsection{Data analysis}

A relative abundance value for weed populations was calculated according to Derksen et al., (1993). This is a synthetic importance value where relative cover was calculated as cover of individuals for a given species for each relevé divided by the total cover of individuals within the relevé. Relative frequency was calculated as proportion of relevés in which the species was present divided by the total frequency of all species. Then, relative abundance values were calculated for each weed species as follows: (relative cover + relative frequency)/2. 
Species diversity from the past and the recent surveys was assessed by calculating different indices. Species richness was expressed as the mean number of species per plot (S-mean) and as total number of species recorded (S-tot). Shannon-Wiener Index of Diversity $\left(H^{\prime}\right)$ was calculated as:

$$
H^{\prime}=-\Sigma\left[\mathrm{p}_{\mathrm{i}} \ln \left(\mathrm{p}_{\mathrm{i}}\right)\right]
$$

where $p_{i}$ is relative importance value of each species (Whittaker, 1975).

Rank-abundance plots were used to provide a description of the community diversity between the past and the recent surveys (Whittaker,1967). This is a very sensitive measure of environmental effect, since it simultaneously shows both components of species diversity, species number and evenness of species abundances (Magurran, 1988).

The variation of the species composition between surveys and habitat types (orchards/vineyards, alfalfa fields, row crops, cereals and ruderal habitats) were analyzed with Canonical Correspondence Analysis (CCA) using CANOCO 5 (ter Braak, Smilauer, 2012). Statistical significance of fitting CCA axes to the relationship between the species and external variables (i.e. habitats types) was tested using a global permutation test (Monte-Carlo test) of the species data at 1000 iterations.

\section{RESULTS AND DISCUSSION}

During the investigations (in 2005 and in 2017) a total of 175 species were identified, belonging to 131 genera and 36 families, which is a similar number of species compared to other surveys done in the Mediterranean region (Cirujeda et al., 2011, Damanakis, 1983).

When comparing different habitats (orchards, alfalfa, row crops, cereals and ruderal areas), a general decline of the species relative abundance from the earlier to the recent survey was evident (Table 1). The most abundant species in 2005 and distributed in all crops and ruderal sites were Avena fatua L., and Setaria verticilata (L.) P. Beauv. Lolium multiflorum Lam. was very frequent in alfalfa crop and ruderal habitats, while Veronica persica Poir. was highly associated with orchards and vineyards. In the recent survey these species became very rare or were even not detected in some habitats (Table 1). However, in Spanish cereal fields (Cirujeda et al., 2011) these species are still considered frequent weeds, although for A. fatua some research had confirmed a long term decline of its population due to different cultivation (Wilson, 1978).

One of the frequent species Ambrosia artemisiifolia L. distributed in 2005 in the Eastern and Southeastern part of the Istrian Peninsula (Kovačević et al., 2008), mainly in ruderal habitats, is nowadays rare and was observed with a very low relative abundance only in row crops. Successful eradication campaigns in the region removed this plant from invaded sites (V. Kovačević, personal communications).

Besides these, other weeds like Dactylis glomerata L., Polygonum persicaria L., Stellaria media (L.) Vill., Panicum milliaceum L., Veronica arvensis L., Equisetum arvense L. were relatively frequent in 2005 , but they diminished considerably over time. 
E. Štefanić, V. Kovačević, S. Antunović: Decline of Arable Flora Diversity in Istria... Zbornik Veleučilišta u Rijeci, Vol. 6 (2018), No. 1, pp. 385-398

Table 1. Mean species relative abundance values for dominant weed species corresponding to surveys done in 2005 and in 2017

\begin{tabular}{|c|c|c|c|c|c|c|c|c|c|c|}
\hline \multirow{2}{*}{$\begin{array}{l}\text { Dominant } \\
\text { Weeds* }\end{array}$} & \multicolumn{2}{|c|}{$\begin{array}{l}\text { Orchards/ } \\
\text { vineyards }\end{array}$} & \multicolumn{2}{|c|}{ Alfalfa } & \multicolumn{2}{|c|}{ Row crops } & \multicolumn{2}{|c|}{ Cereals } & \multicolumn{2}{|c|}{$\begin{array}{l}\text { Ruderal } \\
\text { habitats }\end{array}$} \\
\hline & 2005 & 2017 & 2005 & 2017 & 2005 & 2017 & 2005 & 2017 & 2005 & 2017 \\
\hline AVEFA & 3,8 & $<0,1$ & 6,2 & - & $<0,1$ & - & 6,3 & $<0,1$ & 7,8 & $<0,1$ \\
\hline LOLMU & - & - & 6,8 & $<0,1$ & - & - & - & - & 6,5 & - \\
\hline VERPE & 12,1 & - & - & - & 0,5 & $<0,1$ & $<0,1$ & - & $<0,1$ & - \\
\hline SETVE & 1,5 & $<0,1$ & $<0,1$ & - & 9,8 & - & 0,5 & - & $<0,1$ & - \\
\hline AMBEL & - & - & - & - & - & $<0,1$ & - & - & 8,9 & $<0,1$ \\
\hline CYNDA & 0,5 & 11,1 & - & $<0,1$ & 7,8 & 0,2 & - & - & - & $<0,1$ \\
\hline DACGL & 2,5 & - & $<0,1$ & - & 1,3 & - & - & $<0,1$ & 4,3 & 0,5 \\
\hline POROL & 7,6 & $<0,1$ & - & - & - & - & - & - & $<0,1$ & 3,8 \\
\hline VERAR & - & - & $<0,1$ & - & 0,5 & $<0,1$ & 6,5 & $<0,1$ & $<0,1$ & - \\
\hline POLPE & $<0,1$ & - & - & - & 6,3 & $<0,1$ & 0,5 & - & $<0,1$ & - \\
\hline STEME & 5,4 & $<0,1$ & - & - & 0,9 & - & - & - & 0,3 & - \\
\hline AMARE & 4,2 & 0,2 & - & - & 1,5 & 0,6 & - & - & 0,5 & 6,3 \\
\hline PANMI & - & - & - & - & 6,3 & - & - & - & - & - \\
\hline EQUAR & 1,5 & $<0,1$ & - & $<0,1$ & 4,3 & $<0,1$ & - & - & $<0,1$ & - \\
\hline CONAR & 1,2 & 11,8 & $<0,1$ & $<0,1$ & 2,5 & 0,2 & 1,5 & 6,3 & 0,6 & 3,8 \\
\hline CLVVT & 1,5 & - & - & - & - & 2,3 & - & - & 1,5 & - \\
\hline AGRRE & - & - & 3,3 & $<0,1$ & - & - & $<0,1$ & - & 1,5 & - \\
\hline MERAN & 0,5 & $<0,1$ & - & - & - & 3,8 & 0,1 & - & - & - \\
\hline KNAAR & - & $<0,1$ & $<0,1$ & - & - & - & 0,5 & - & 3,5 & - \\
\hline ERXCA & - & - & $<0,1$ & - & - & - & - & - & 3,7 & - \\
\hline XANST & - & $<0,1$ & - & - & 3,8 & - & - & - & - & $<0,1$ \\
\hline RUSPP & - & $<0,1$ & - & $<0,1$ & - & 0,5 & - & $<0,1$ & 3,1 & 0,5 \\
\hline PLALA & 0,5 & $<0,1$ & $<0,1$ & 0,1 & $<0,1$ & - & - & - & 2,0 & - \\
\hline SORHA & 1,5 & 3,8 & - & 0,1 & 0,5 & 0,5 & - & 0,1 & 0,5 & - \\
\hline CAGSE & 1,5 & $<0,1$ & - & - & $<0,1$ & $<0,1$ & 0,5 & - & $<0,1$ & - \\
\hline CIRAR & 2,0 & $<0,1$ & - & 0,1 & $<0,1$ & 0,1 & - & $<0,1$ & $<0,1$ & - \\
\hline SETVI & $<0,1$ & 0,1 & $<0,1$ & 0,5 & 1,5 & 3,8 & - & $<0,1$ & $<0,1$ & 0,1 \\
\hline ECHCG & $<0,1$ & $<0,1$ & - & - & 1,5 & 0,1 & - & - & - & - \\
\hline CHEAL & $<0,1$ & 0,1 & - & - & 0,5 & 0,1 & $<0,1$ & - & 0,5 & 6,3 \\
\hline DAUCA & $<0,1$ & 3,7 & 0,5 & $<0,1$ & $<0,1$ & 0,1 & 0,5 & 0,5 & $<0,1$ & 3,8 \\
\hline ERICA & - & 4,0 & 0,5 & - & $<0,1$ & - & - & - & - & $<0,1$ \\
\hline POLAV & - & 6,5 & - & - & $<0,1$ & $<0,1$ & $<0,1$ & 3,8 & $<0,1$ & - \\
\hline MENLO & - & 0,6 & $<0,1$ & - & $<0,1$ & 0,5 & - & 0,5 & $<0,1$ & 0,5 \\
\hline PAVSA & - & 3,8 & - & $<0,1$ & - & - & - & $<0,1$ & $<0,1$ & - \\
\hline PICEC & - & 4,4 & - & - & - & $<0,1$ & - & 0,1 & - & - \\
\hline HEOEU & - & - & - & - & - & $<0,1$ & - & 3,8 & - & $<0,1$ \\
\hline
\end{tabular}

*Bayer Code for weeds: AVEFA (Avena fatua), LOLMU (Lolium multiflorum), VERPE (Veronica persica), SETVE (Setria verticilata), AMBEL (Ambrosia artemisiifolia), CYNDA (Cynodon dactylon), DACGL (Dactylis glomerata), 


\section{E. Štefanić, V. Kovačević, S. Antunović: Decline of Arable Flora Diversity in Istria... Zbornik Veleučilišta u Rijeci, Vol. 6 (2018), No. 1, pp. 385-398}

POROL (Portulaca oleracea), POLPE (Polygonum persicaria), STEME (Stellaria media), AMARE (Amaranthus retroflexus), PANMI (Panicum miliaceum), VERAR (Veronica arvensis), EQUAR (Equisetum arvense), CONAR (Convolvulus arvensis), CLVVT (Clematis vitalba), AGRRE (Agropyron repens), MERAN (Mercurialis annua), KNAAR (Knautia arvensis), ERXCA (Eryngium campestre), XANST (Xanthium strumarium), RUSPP (Rubus spp.), PLALA (Plantago lanceolata), SORHA (Sorghum halepense), CAGSE (Calystegia sepium), CIRAR (Cirsium arvense), SETVI (Setaria viridis), ECHCG (Echinochloa crus-galli), CHENAL (Chenopodium album), DAUCA (Daucus carota), ERICA (Conyza canadensis), POLAV (Polygonum aviculare), MENLO (Mentha longifolia), PAVSA (Pastinaca sativa), PICEC (Picris echioides), HEOEU (Heliotropium europaeum)

Note: weed species are sorted according to their highest mean relative abundance values

In contrast, some species with a very low relative abundance or those not recorded in the earlier survey were found abundant in 2017 (Table 1). These are: Pastinaca sativa L., Conyza canadensis (L.) Cronquist., Picris echioides L. and Polygonum aviculare L. in orchards and vineyards and Heliotropium europaeum L. in cereals.

However, rhizomatous perennials Cynodon dactylon (L.) Pers. and Convolvulus arvensis L. which were dominant in row crops in 2005 , became the most abundant species in the recent survey on regional scale as well as significantly dominant in orchards and vineyards (Table 1). Such increase in the dominance, particularly in permanent crops (orchards and vineyards) could also be explained with cropping conditions, e.g. cultivation, because they propagate mainly vegetatively, through stolon and rhizome fragmentation (Fernandez, 2003).

Weed communities characteristics are shown in Table 2. The comparison of the weed communities in investigated area in 2005 and the present reflects the reduction of weed flora at the regional and at the field scale. The total species richness was significantly higher in 2005 when eighty-two percent of the total number of weed species (143 species in 110 genera) were sampled. In the recent survey fifty-five percent of the total number of weed species ( 97 species in 82 genera) were found. Sixty four species were common in both surveys, and these were considered frequent weeds.

These losses are consistent with the results of many studies, for example in Germany (Meyer et al., 2013), in the Czech Republic (Tyser et al., 2009), or Spain (Cirujeda et al., 2011). On the whole, all the drivers that have been leading to decline of arable weeds could be interpreted in the context of the balance between seed return and seed bank declines due to the increased use of herbicides and inorganic fertilizers (Gerowitt et al., 2018). 
Table 2. Community characteristics of investigated habitats in surveys done 2005 and 2017

\begin{tabular}{|c|c|c|c|c|c|c|}
\hline \multirow{2}{*}{$\begin{array}{c}\text { Habitat } \\
\text { type }\end{array}$} & \multicolumn{6}{|c|}{ Community characteristics } \\
\cline { 2 - 7 } & \multicolumn{4}{|c|}{2005} & \multicolumn{3}{c|}{2017} & $H^{\prime}$ \\
\cline { 2 - 7 } & S-tot & S-mean & $H^{\prime}$ & S-tot & S-mean & 2,264 \\
\hline $\begin{array}{c}\text { Orchards/ } \\
\text { vineyards }\end{array}$ & 45 & 15 & 2,766 & 66 & 16 & 0,868 \\
\hline Alfalfa & 39 & 16 & 1,754 & 24 & 8 & 0,846 \\
\hline Row crops & 50 & 15 & 2,512 & 36 & 14 & 0,662 \\
\hline Cereals & 43 & 17 & 2,067 & 25 & 15 & 0,888 \\
\hline $\begin{array}{c}\text { Ruderal } \\
\text { habitats }\end{array}$ & 85 & 22 & 2,719 & 31 & 17 & 1,202 \\
\hline Total & 143 & 18 & 3,290 & 97 & 14 & \\
\hline
\end{tabular}

S-tot $=$ total number of species recorded

$\mathrm{S}$-mean = mean species number per relevé

$\mathrm{H}^{\prime}=$ species diversity (Shannon-Wiener index $\mathrm{H}^{\prime}$ )

Exceptions in this research were orchards and vineyards where a significant increase in the total number of species (47\%) was detected (Table 2). Although mean species per relevé and $H^{\prime}$ were similar, only 25 weeds were common to both surveys (data not shown). Weed control practice in grapevine, olive orchards and other permanent crops in Istria are mainly oriented to mechanical (inter-row) cultivation. Such non-chemical weed control practice influence weed communities on vineyards and orchard floor allowing many weed species with low abundance and/or inconsistent occurrence to develop (Baumgartner et al., 2007). 
Graph 1. Rank abundance plots corresponding to surveys done in 2005 and in 2017
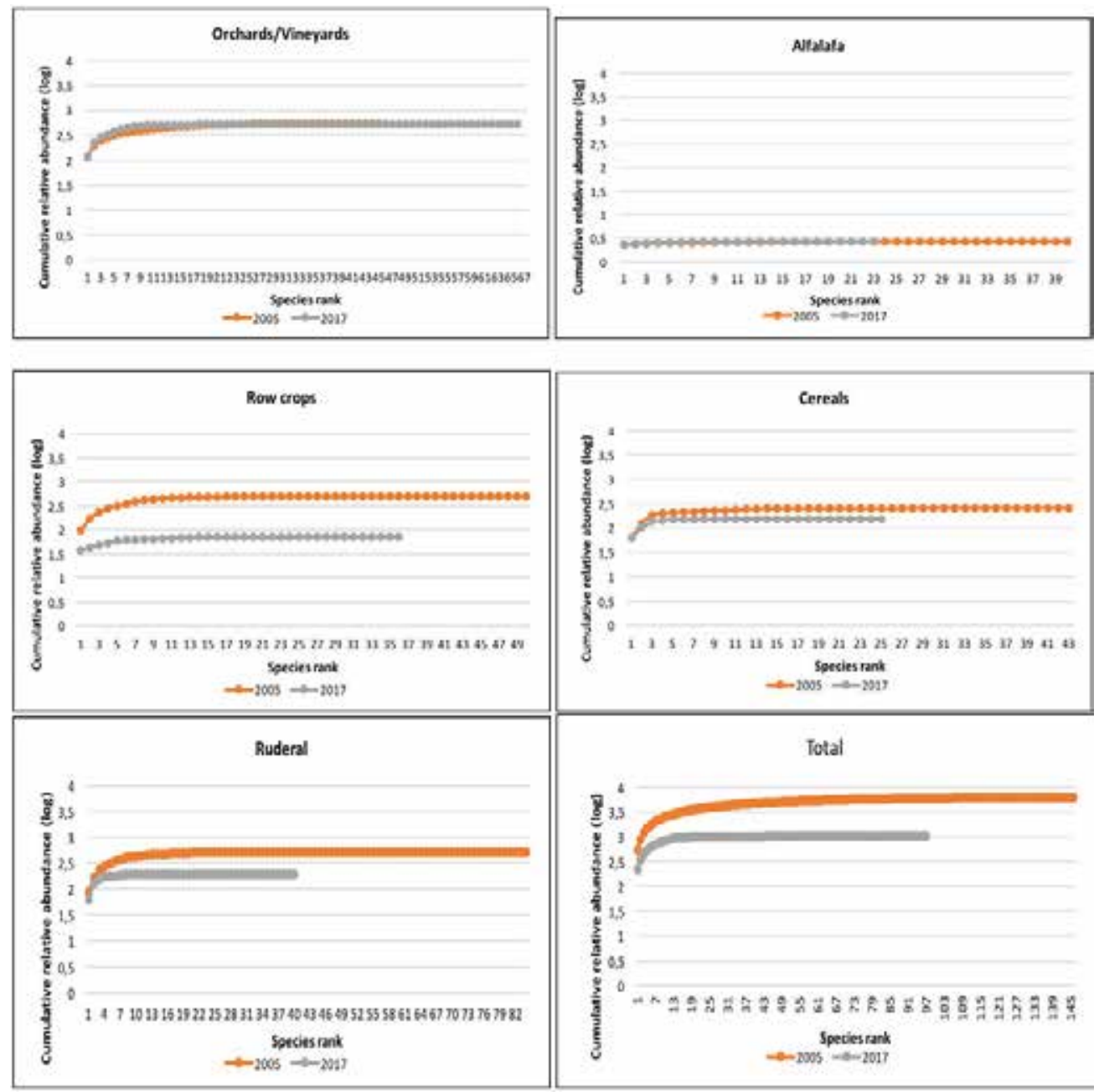

Source: authors

The mean values of Shannon-Wiener diversity index $\left(H^{\prime}\right)$ was also higher in 2005 and it decreased over time (Table 2). Particularly significant decrease in diversity was observed in row crops, cereals and ruderal habitats. This decrease of Shannon-Wiener's diversity index $\left(\mathrm{H}^{\prime}\right)$ is related to the decline of species richness, and to the increase in inequality in the relative abundance of species (Graph 1). This result was consistent with Roschewitz et al., (2005) who reported that species diversity decreased where the intensification of agriculture was higher and more complex. Thus, less intensive weed management in orchards and vineyards is beneficial for the higher weed diversity. 
Moreover, eveness of weed communities was changed over time (Graph 1). In each habitat a reduction of abundance of dominant species was evident in 2017. This is shown by the slope of the rank-abundance plots, and in the reduced number of the rare species in the curve tail. Probably, this is result of agricultural intensification, as it was observed in other areas of Europe (Baessler, Klotz, 2005).

Graph 2. Ordination diagrams from Cannonical Correspondence Analysis corresponding to surveys done in:
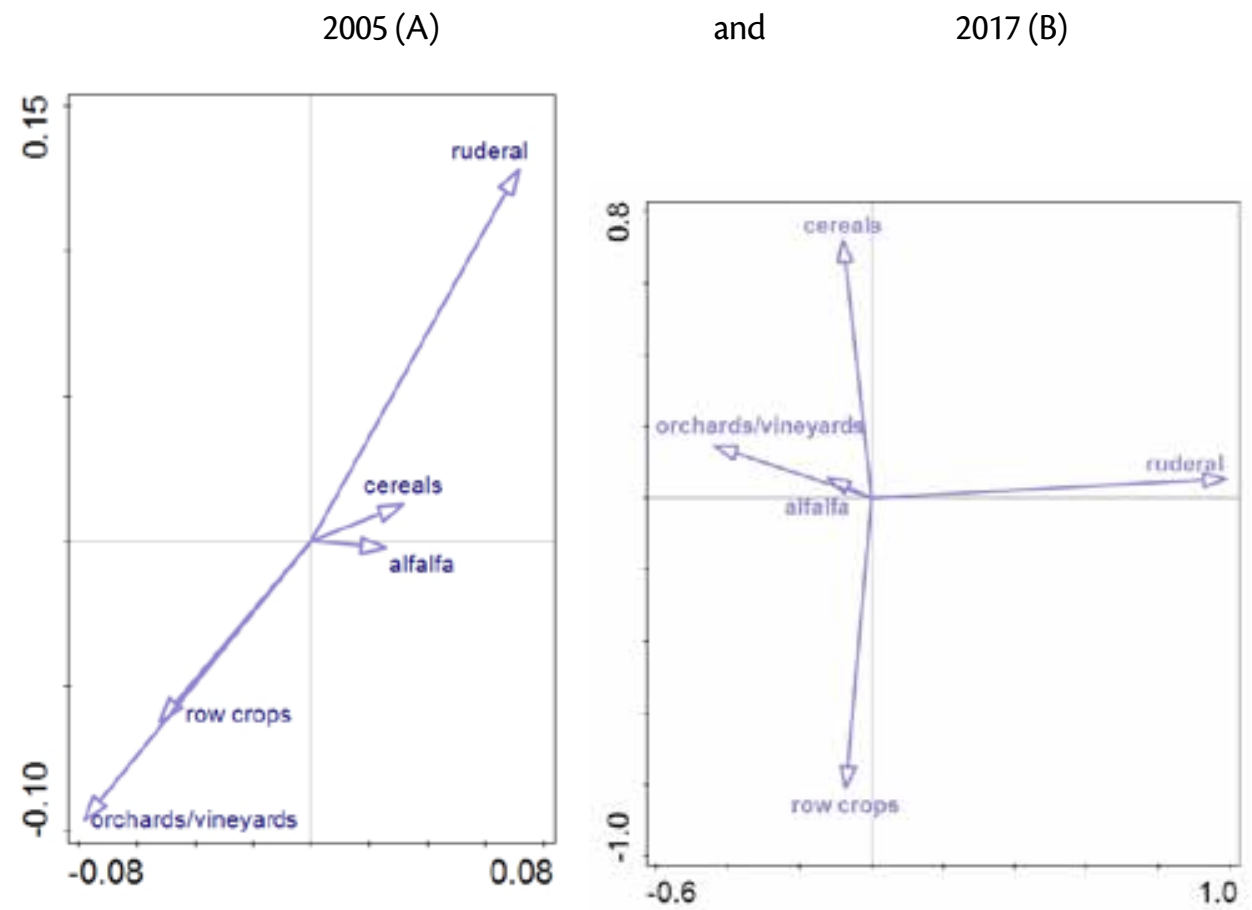

Source: authors

The results of this research also reveal changes in the relationships between weed communities and crops. The output of Cannonical Correspondence Analysis was presented in Graph 2. and Table 2. showing the shifts between weed community association and main crop types in Istria.

The first two axis in 2005 explained $40 \%$ of the variance (axis 1 explained 24,2 and axis 2 15,8\% of variance, respectively, Table 2). The length and the position of the arrows suggest a highly positively correlated weed community in row crops and in permanent crops and negatively correlated with ruderal habitats.

The decrease of the species richness and diversity over the period of 12 years is reflected on the weed community composition in 2017 . On the basis of CCA analysis, 32,4\% of the total variation in the species data was explained by the first two axes (Table 3). Axis 1 explained 19,7\% of the 


\section{E. Štefanić, V. Kovačević, S. Antunović: Decline of Arable Flora Diversity in Istria... Zbornik Veleučilišta u Rijeci, Vol. 6 (2018), No. 1, pp. 385-398}

variation and clearly separated weed community in ruderal habitats from those in orchards/ vineyards, alafalfa, cereals and row crops. Based on the second axis, which explained further $12,7 \%$ of variations, distinguished weed community in row crops from other agricultural habitats.

Cropping characteristics, particularly row spacing, clearly showed significant association of weed communities in 2005. but not in 2017. Although Gunton et al. (2011) found crop characteristics superior predictor of weed community composition than crop types, this research did not detect the same pattern in the previous and recent surveys.

Table 3. Results from the Canonical Correspondence Analysis (CCA)

\begin{tabular}{|c|c|c|c|c|c|}
\hline \multirow[b]{2}{*}{ Axis loadings } & \multicolumn{4}{|c|}{ Axes } & \multirow{2}{*}{$\begin{array}{l}\text { Total } \\
\text { inertia }\end{array}$} \\
\hline & 1 & 2 & 3 & 4 & \\
\hline \multicolumn{5}{|c|}{2005} & \\
\hline Eigenvalues & 0,521 & 0,436 & 0,279 & 0,151 & 2,762 \\
\hline Species-environment correlations & 0,970 & 0,955 & 0,903 & 0,868 & \\
\hline \multicolumn{6}{|l|}{ Cumulative percentage variance } \\
\hline of species data & 24,2 & 40,0 & 53,1 & 59,7 & \\
\hline of species-environment relation & 30,6 & 57,9 & 78,6 & 87,2 & \\
\hline \multicolumn{5}{|c|}{2017} & \\
\hline Eigenvalues & 0,379 & 0,237 & 0,176 & 0,125 & 2,116 \\
\hline Species-environment correlations & 0,852 & 0,799 & 0,701 & 0,634 & \\
\hline \multicolumn{6}{|l|}{ Cumulative percentage variance } \\
\hline of species data & 19,7 & 32,4 & 39,1 & 42,3 & \\
\hline of species-environment relation & 24,9 & 44,7 & 57,4 & 62,6 & \\
\hline
\end{tabular}

\section{CONCLUSION}

The comparison of weed communities in 2005 and in 2017 surveys implies the reduction of the weed flora in 50 investigated agricultural plots in Istria. In 2005 Avena fatua L. and Setaria verticilata (L.) P. Beauv were the most abundant species distributed in all crops and ruderal sites. Very frequent in alfalfa crop and ruderal habitats was Lolium multiflorum Lam., while Veronica persica Poir. was highly associated with orchards and vineyards. In the recent survey these species became very rare or were even not detected in some habitats. In contrast, some species with very low relative abundance or not recorded in the earlier survey were found abundant in 2017. These are: Pastinaca sativa L., Conyza canadensis (L.) Cronquist., Picris echioides L. and Polygonum aviculare L. in orchards and vineyards and 
Heliotropium europaeum L. in cereals. Rhizomatous perennials Cynodon dactylon (L.) Pers. and Convolvulus arvensis L. which were dominant in row crops in 2005 , became the most abundant species in the recent survey on regional scale as well as significantly dominant in orchards and vineyards.

The decrease of species richness (total and per relevé) was confirmed in all habitats types, except orchards and vineyards. The dramatic loss of biodiversity was evident in row crops, cereals and ruderal habitats. Besides the decline of species richness and diversity over the period of 12 years, significant changes happened inside the floristic composition. As expected, ruderal weed community floristically differs from other investigated habitats in 2005 and in 2017. Row spacing clearly showed significant association of weed communities in 2005 but not in 2017 indicating fluctuational rather than structural changes in weed communities.

\section{REFERENCES}

Albrecht, H. (1995) Changes in the arable weed flora of Germany during the last five decades. In: Proceedings $19959^{\text {th }}$ EWRS Symposium - Challenges for Weed Science in a Changing Europe, Budapest, Hungary, 41-48.

Andreasen, C., Streibig, J.C. (2010) Evaluation of changes in weed flora in arable fields of Nordic countries- based on Danish long-term surveys. Weed Res. 51, 214-226.

Baessler, C., Klotz, S. (2006) Effects of changes in agricultural land-use on landscape structure and arable weed vegetation over the last 50 years. Agriculture, Ecosystems \& Environment 115, 43-50.

Barberi, P., Cozzani, A., Macchia, M., Bonari, E. (1998) Size and composition of weed seedbank under different management systems for continuous maize cropping. Weed Research 38, 319-334.

Barberi, P., Lo Cascio, B. (2001) Long-term tillage and crop rotation effects on weed seedbank size and composition. Weed Research 41, 325-340.

Baumgartner, K., Steenwerth, K.L., Veilleux, L. (2007) Effect of organic and conventional practices on weed control in a perennial cropping system. Weed Sci. 55, 352-358.

Braun-Blanquet, J. (1964) Pflanzensoziologie, Grundzüge der Vegetationskunde. (3. Auflage). Springer Verlag, Wien, 865 pages.

Cirujeda, A., Aibar, J., Zaragoza, C. (2011) Remarkable changes of weed species in Spanish cereal fields from 1976 to 2007. Agronomy Sust. Developm. 31, 675-688.

Damanakis, M. (1983) Weed species in wheat fields of Greece - 1982, 1983 survey. Zizaniology 1, 85-90.

Derksen, D.A., Lafond, G.P., Thomas, A.G., Loeppky, H.A., Swanton, C.J. (1993) Impact of Agronomic Practices on Weed Communities: Tillage Systems. Weed Science 41, 409-417.

Fernandez, O.N. (2003) Establishment of Cynodon dactylon from stolon and rhizome fragments. Weed Research 43, 130-138.

Gaba, S., Perronne, R., Fried, G., Gardarian, A., Bretagnolle, F., Biju-Duval, L., Colbach, N., Cordeau, S., Fernández-Aparicio, M., Gauvrit, C., Fibot=Leclerc, S., Gulliemin, J.P., Moreau, D., Munier-Jolan, N., Strbik, F., Rebud, X. (2017) Respone and effect traits of arable weeds in agro-ecosystems: a review of current knowledge. Weed Research 57, 123-147.

Gerowitt, B., Bàrberi, P. Darmency, H., Petit, S., Storkey, J., Westerman, P. (2018) Weed Research:Expanding Horizons. First Ed., John Wiley \& Sons Ltd.

Gunton, R.M., Petit, S., Gaba, S. (2011) Functional traits relating arable weed communities to crop characteristics. Journal of Vegetation Science. Doi:10.1111/j.1654-1103.2011.01273.x 
Hilbig, W., Bachthaler, G. (1992) Wirthschaftsbedingte Veränderungen der Segetalvegetation in Deutschland in Zeitraum von 1950 - 1990. Journal of Applied Botany 66, 192-200.

Hulina, N. (1998) Rare, endangered or vulnerable plants and neophytes in a drainage system in Croatia. Nat. Croat. 7(4), 279-289.

Hulina, N. (2005) List of Threatened Weeds in the Continental Part of Croatia and Their Possible Conservation. Agric.conspec.sci. 70(2), 37-42.

Kolarova, M., Tyser, L., Soukup, J. (2013) Impact of site conditions and farming practices on the occurrence of rare and endangered weeds on arable land in the Czech Republic. Weed Research 53, 489-498.

Kovačević, V., Horvat, V., Štefanić, E., Rašić, S. (2008) Ragweed in Istria peninsula: distribution and pollen production. 2nd International Symposium "Intractable Weeds and Plant Invaders" Osijek

Lososová, Z., Simonová, D. (2008) Changes during the $20^{\text {th }}$ century in species composition of synanthropic vegetation in Moravia (Czecz Republic). Preslia 80, 71-79.

Magguran, A.E. (1988) Ecological Diversity and its Measurements. Princeton University Press, Princeton.

Marshall, E.J.P., Moonen, A.C. (2002) Field margins in northern Europe: their functions and interactions with agriculture. Agriculture, Ecosystems \& Environment 89, 5-21.

Meyer, S., Wesche, K., Krause, B., Leuschner, C. (2013) Dramatic losses of specialist arable plants in Central Germany since the 1950/60s- a cross regional analysis. Divers. Distrib. 19, 1175-1187.

Racz, Z. (2003) Pedologija za studente stručnih studija. Veleučilište u Rijeci. Poljoprivredni odjel u Poreču

Roschewitz, I., Gabriel, D., Tscharntke, T., Thies, C (2005) The effects of landscape complexity on arable weed species diversity in organic and conventional farming. Journal of Applied Ecology 42, 873-882.

Richner, N., Linder, H.P., Holderegger, R., Walter, T. (2014) Reviewing change in the arble flora of Europe: a meta analysis. Weed Res. 55, 1-13.

Storkey, J., Moss, S.R., Cussans, J.W. (2010) Using assembly theory to explain changes in a weed flora in response to agricultural intensification. Weed Science 58, 39-46.

Storkey, J., Meyer, S., Still, K.S., Leuschner, C. (2012) The impact of agricultural intensification and land-use change on the European arable flora. Proceedings of the Royal Society B-Biological Sciences, 279, 1421-1429.

Sutclife, O.L., Kay, Q.O.N. (2000) Changes in the arable flora of central southern England since 1960. Biol. Conserv. 93, 1-8.

Ter Braak, C.J.F., Smilauer, P. (2012) Canoco Reference Manual and User's Guide. Software for Ordination (version 5.0). Biometris, Wageningen and České Budêjovice.

Tyser, L., Hamouz, P., Nováková, K., Necasová, M., Holec, J. (2009) Changes in weed communities on selected areas with 30 years intervals. Scientia Agriculturae Bohemica 40, 18-25.

Van Der Maarel, E. (1979) Transformation of cover-abundance values in phytosociology and its effect on community similarity. Vegetatio 39, 97-114.

Whittaker, R.H. (1975) Communities and Ecosystems. second ed. Macmillan Publishing Co., Inc., NY

Wilson, B.J. (1978) The long term decline of a population of Avena fatua L., with different cultivations asociated with spring barley cropping. Weed Research 18, 25-31. 


\section{SMANJENJE RAZNOLIKOSTI FLORE NA OBRADIVIM POVRŠINAMA ${ }^{4}$}

\section{SAŽETAK}

Promjene u florističkom sastavu korovne flore Istre procijenjenje su putem dvije fitocenološke analize vegetacije izvršene tijekom 2005. i 2017. godine. U oba istraživanja pregledano je 50 polja korištenjem kombinirane procjene brojnosti i pokrovnosti vrsta metodom po Braun-Blanquetu. Ukupno je na istraživanom području evidentirano 175 vrsta vaskularne flore. Najvećom abundacijom u 2005. isticale su se Avena fatua, Setaria verticilata, Lolium multiflorum i Veronica persica, dok su u 2017. bile vrlo rijetke ili su čak nestale s nekih staništa. Nasuprot tome, neki korovi koji su bili neznatno zastupljeni ili ih nije bilo u ranijem istraživanju zabilježeni su s visokom abundacijom u istraživanjima 2017. godine. To su vrste Pastinaca sativa, Conyza canadensis, Picris echioides, Polygonum aviculare i Heliotropium europaeum. Floristički su bogatija bila istraživanja iz 2005. godine kada je utvrđeno 143 vrste korova (82 \%) u odnosu na istraživanja izvršena 2017. kada je zabilježeno samo 97 vrsta, odnosno $55 \%$ od ukupno evidentirane flore. Zajedničke u oba istraživana razdoblja bile su 64 korovne vrste koje pripadaju tipičnim i frekventnim korovima istraživanog područja. Promjene unutar korovnih zajednica utvrđene su ne samo na regionalnoj razini veći i unutar samih polja. Na to ukazuje i smanjenje ShannonWienerova indeksa raznolikosti $\left(H^{\prime}\right)$, posebice u okopavinama, žitaricama i na ruderalnim staništima. $\mathrm{Na}$ smanjenje Shannon-Wienerova indeksa raznolikosti utjecala je redukcija broja vrsta kao i njihova nejednaka abundacija. U konačnici, multivarijantna analiza (CCA) potvrdila je fluktuacije u florističkom sastavu korovne zajednice.

Ključne riječi: bioraznolikost, korovna flora, kartiranje flore, Istra, Hrvatska

1 Dr. sc., prof. dr. sc., Poljoprivredni fakultet, Sveučilište u Osijeku, V. Preloga 1, 54000 Osijek, Hrvatska. E-mail: estefanic@pfos.hr

2 Dr. sc., viši predavač, veleučilište u Rijeci, K. Huguesa, 52440 Poreč, Hrvatska.E-mail: vesna.kovacevic@veleri.hr

3 Dr. sc., prof. v. š., Veleučilište u Slavonskom Brodu, Dr. M. Budaka 1, 35000 Slavonski Brod, Hrvatska. E-mail: slavica.antunovic@vusb.hr

4 Datum primitka rada: 15. 1. 2018.; datum prihvaćanja rada: 15. 3. 2018. 
